ks. Tadeusz Panuśs

Uniwersytet Papieski Jana Pawła II w Krakowie

\title{
Religijny portret młodego uczestnika Światowych Dni Młodzieży 2016
}

Niewątpliwie o religijnym obliczu Kościoła w najbliższych dziesiątkach lat decydować będzie obecne pokolenie ludzi młodych. Warto więc zadać sobie pytanie: jaka jest kondycja religijno-moralna współczesnej młodzieży? W udzieleniu odpowiedzi na tę kwestię pomocne będą badania uczestników Światowych Dni Młodzieży, jakie odbyły się pod koniec lipca 2016 roku w polskich diecezjach, a następnie już z papieżem Franciszkiem w Krakowie. Badania te, zatytułowane Etapy socjalizacji religijnej i elementy postaw religijnych uczestników Światowych Dni Młodzieży w 2016 roku, przeprowadził Instytut Statystyki Kościoła Katolickiego na zlecenie Wydziału Teologicznego Uniwersytetu Kardynała Stefana Wyszyńskiego w Warszawie (UKSW) ${ }^{2}$.

1 Ks. prof. dr hab. Tadeusz Panuś - kapłan archidiecezji krakowskiej, kierownik Katedry Katechetyki Wydziału Teologicznego UPJPII w Krakowie; rzeczoznawca ds. oceny programów nauczania religii i podręczników katechetycznych Komisji Wychowania Katolickiego Konferencji Episkopatu Polski; konsultor Komisji Wychowania Katolickiego Konferencji Episkopatu Polski; członek Polskiego Towarzystwa Teologicznego i Stowarzyszenia Katechetyków Polskich.

2 Podobne badania przeprowadził zespół socjologów religii we współpracy z Instytutem Statystyki Kościoła Katolickiego oraz Narodowym Centrum Kultury jesienią 2016 roku. Zob. Odbiór Światowych Dni Młodzieży i jego kulturowe konteksty. Raport z badania uczestników Światowych Dni Młodzieży Kraków 2016, http://iskk.pl/kosciol-na-swiecie/251-world-youth-day (18.04.2017). 
W poniższym artykule omówimy następujące kwestie:

1. Czym są Światowe Dni Młodzieży?

2. Światowe Dni Młodzieży w Polsce i w Krakowie.

3. Metodologia przeprowadzonych badań.

4. Elementy postaw religijnych.

5. Trajektorie socjalizacji religijnej.

6. Wnioski końcowe.

W poniższym artykule pragnę omówić wyżej sformułowane zagadnienia.

\section{Czym są Światowe Dni Młodzieży?}

Światowe Dni Młodzieży (ŚDM) to modlitewne spotkania młodych ludzi z różnych krajów. Co dwa lub trzy lata przyjmują formę wielkiego spotkania młodych wiernych z ojcem świętym w wyznaczonym przez niego miejscu na świecie. Młodzi ludzie przez kilka dni modlą się, słuchają papieskich nauk, przyjmują sakramenty, ale teź śpiewają, tańczą, biorą udział w wydarzeniach artystycznych, towarzyskich, a nawet sportowych. Za każdym razem ŚDM mają formę festiwalu religijno-kulturalnego. Tematyka corocznych spotkań wyznaczana jest przez ojca świętego ${ }^{3}$. Papież kieruje do młodych orędzie, którego treści są rozważane podczas spotkań w parafiach. Każde ze Światowych Dni Młodzieży miało też swoje hasło, zwykle zaczerpnięte z Pisma Świętego. Na termin spotkania najczęściej wybierany jest okres wakacji, stąd też ŚDM organizowane są zazwyczaj w lipcu lub sierpniu ${ }^{4}$.

Pierwotnie centralne obchody ŚDM obejmowały tylko wieczorne czuwanie modlitewne z papieżem w sobotę oraz mszę świętą pod jego przewodnictwem w niedzielę rano. W 1989 roku organizatorzy dodali trzy

3 Na drogach wiary z młodzieżą świata, w: Pielgrzymka odwagi i nadziei. Franciszek w Polsce z młodzieżą świata. ŚDM Kraków 2016, red. J. Sosnowska, Kraków 2016, s. 9.

4 Wyjątek stanowiły ŚDM w Manili w 1995 roku, które odbyły się w styczniu, i w Buenos Aires, które były w kwietniu 1987 roku. Wyjątkiem od tej tradycji będą też34 ŚDM w Panamie, zaplanowane na dni 22-27 stycznia 2019 roku. 
dni katechez poprzedzających sobotnio-niedzielne spotkanie z ojcem świętym, w 1991 roku powitanie go przez młodzież, a w 1993 - piątkowe nabożeństwo drogi krzyżowej. Z kolei w 1995 roku pojawił się festiwal młodych o charakterze kulturalnym, a także możliwość spędzenia wcześniej kilku dni w jednej z diecezji, by poznać życie miejscowego Kościoła. W 2000 roku dodano strefę sakramentu pojednania, a w 2005 podczas sobotniego czuwania po raz pierwszy odbyła się adoracja eucharystyczna. W 2008 roku pojawiły się targi powołaniowe, na których zgromadzenia zakonne i wspólnoty, przedstawiając swoje działania i cele, zachęcają do wybrania drogi życia konsekrowanego 5 .

Po raz pierwszy Jan Paweł II spotkał się z młodymi ludźmi w Rzymie w Niedzielę Palmową 15 kwietnia 1984 roku z okazji Nadzwyczajnego Jubileuszu Odkupienia. Tydzień później, w Niedzielę Wielkanocną 22 kwietnia, przekazał im Krzyż Roku Świętego i wygłosił przemówienie będące jednocześnie wezwaniem: „Zanieście w świat Krzyż Chrystusa jako znak miłości”. Rok później, 29 marca 1985 roku, odbyło się ponowne jego spotkanie z młodymi. Okazją było ogłoszenie przez ONZ Międzynarodowego Roku Młodzieży. Wieczorem na placu przed Bazyliką św. Jana na Lateranie zebrało się ok. 300 tys. osób przybyłych na zaproszenie ojca świętego z całego świata. Odmówiono wspólnie modlitwę o pokój, a papież wygłosił przemówienie zatytułowane Wezwani do uczestnictwa i dawania świadectwa Chrystusowi

Za dzień ustanowienia Światowych Dni Młodzieży uznaje się 20 grudnia 1985 roku. Wtedy to Jan Paweł II na spotkaniu opłatkowym wyraził pragnienie, by te dni odbywały się regularnie co roku w Niedzielę Palmową jako spotkanie diecezjalne wspólnie z jej ordynariuszem, a co dwa lub trzy lata w wyznaczonym przez niego miejscu jako spotkanie międzynarodowe.

Pierwsze Światowe Dni Młodzieży odbyły się w Rzymie w Niedzielę Palmową 23 marca 1986 roku. Ich temat brzmiał: „Abyście umieli zdać sprawę z nadziei, która jest w was". Jan Paweł II ogłosił oficjalnie, że każda Niedziela Palmowa będzie odtąd co roku Światowym Dniem Młodzieży.

5 Na drogach wiary z młodzieża świata, dz. cyt., s. 9.

6 Na drogach wiary z młodzieżą świata, dz. cyt., s. 9. 
W homilii wygłoszonej na Placu św. Piotra wyjaśnił: „To właśnie znaczy «Dzień Młodzieży»: wyjście na spotkanie Boga, który wszedł w dzieje człowieka poprzez tajemnicę paschalną" ' Zgodnie z życzeniem papieża Jana Pawła II Światowe Dni Młodzieży na szczeblu diecezjalnym odbywają się co roku w Niedzielę Palmową.

Ideę Światowych Dni Młodzieży podjęli następcy św. Jana Pawła II, Benedykt XVI i Franciszek. Pierwsze Światowe Dni Młodzieży bez udziału Jana Pawła II odbyły się w Kolonii pod przewodnictwem Benedykta XVI ${ }^{8}$. W Polsce Światowe Dni Młodzieży odbyły się dwukrotnie: w sierpniu 1991 roku w Częstochowie i ostatnio w lipcu 2016 roku w Krakowie.

\section{2. Światowe Dni Młodzieży w Polsce i w Krakowie}

Światowe Dni Młodzieży, które odbyły się w Polsce latem 2016 roku, były największym wydarzeniem z udziałem młodych, jakie miało miejsce w naszym kraju w XXI wieku. W jego przygotowanie zaangażowało się wiele instytucji oraz duża rzesza nie tylko Polaków. ŚDM zarówno w części centralnej - w Krakowie, jak i regionalnej - w diecezjach - były przede wszystkim wydarzeniem o charakterze religijnym i duszpasterskim. Były swoistą pielgrzymką całego Kościoła do Polski, a przede wszystkim młodych na spotkanie z papieżem Franciszkiem w Krakowie.

Światowe Dni Młodzieży są ważnym elementem duszpasterstwa młodzieży, którego podstawowym celem jest doprowadzenie młodych ludzi do dojrzałości w wierze, tak aby stali się świadkami Chrystusa. Znakomitą ilustracją tego jest działanie Chrystusa wobec młodego człowieka pytającego, jak ma żyć, aby osiągnąć życie wieczne (Mt 19, 16-22; Mk 10, 17-22, i Łk 18, 18-23) ${ }^{9}$. Wielorakie propozycje współczesnego świata, które jawią się jako alternatywne drogi życia, są źródłem różnych dylematów młodych ludzi. Nierzadko są oni oczarowani możliwościami, jakie oferuje

7 Na drogach wiary z młodzieżą świata, dz.cyt., s. 13.

$8 \quad$ Na drogach wiary z młodzieżą świata, dz. cyt., s. 24.

9 A. Długosz, Młodzieży duszpasterstwo, w: Encyklopedia katolicka, t. 12, red. A. Bednarek, Lublin 2008, s. 1444. 
„świat”, a które stoją w sprzeczności z Ewangelią i zasadami moralności chrześcijańskiej. Zdarza się ponadto, że młodzież - nie mając doświadczenia życiowego lub dobrych wzorców ze strony dorosłych - dokonuje błędnych wyborów. W takiej sytuacji konieczne jest nawrócenie człowieka, rozumiane jako poszukiwanie Boga i dążenie do zjednoczenia z $\mathrm{Nim}^{10}$. Zadaniem Kościoła jest podprowadzenie młodych do Jezusa i umożliwienie podjęcia przez nich dialogu z Tym, który ma słowa życia wiecznego (por. J 6, 68). Temu też służą Światowe Dni Młodzieży.

Stanowią one także ciekawy materiał badawczy dla socjologów religii, duszpasterzy i zwykłych wiernych. Na ulicach polskich miast mieliśmy bowiem do czynienia z barwnym przemieszaniem starych i nowych form pobożności z całego świata: gestami, tańcami, śpiewami, świadectwami, pokazami różnych sztuk i licznymi formami ekspresji religijnej. Wypowiedzi uczestników ŚDM wskazywały na unikalność tego doświadczenia, jakże odmiennego od codziennej rutyny religijnej. Specyficzne warunki i kontekst spotkania stworzyły nagle „okazje wiary”. Młodzi byli zmęczeni, zmagali się z rozmaitymi problemami, ale jednocześnie całkowicie zapominali o sobie na rzecz bycia z innymi, których oswajali i przez których sami byli oswajani. Jak podkreśla socjolog Maria Rogaczewska, to "zapomnienie o sobie" miało walor intensywności, która także otwierała ich na głębszą, religijną interpretację tego doświadczenia - widzieli w gościach osoby, które przyjechały do nich zgodnie z wolą Boga, i czuli się odpowiedzialni za to, aby Bóg w tych spotkaniach był obecny ${ }^{11}$.

ŚDM stanowiły też ogromny wysiłek organizacyjny oraz aktywizacyjny młodzieży, który nie pozostał bez wpływu na religijność polskiego społeczeństwa, przede wszystkim zaś młodego pokolenia. Nie bez znaczenia był również wpływ Światowych Dni Młodzieży, zwłaszcza poprzez media, na ogólny wizerunek Kościoła oraz miejsce wiary w przestrzeni publicznej. Światowe Dni Młodzieży były więc wielkim wydarzeniem. Pogłębione badania socjologiczne fenomenu ŚDM pokazały, że przeży-

10 D. Lipiec, Teologiczne podstawy duszpasterstwa młodzieży, „Warszawskie Studia Pastoralne UKSW" 2 (2014), s. 11-12.

11 M. Rogaczewska, Znudzeni rutyna, „W Drodze” 4 (2017), s. 87-88. 
cia uczestników były bardzo różnorodne i bogate. Przyjrzyjmy się tym badaniom.

\section{Metodologia przeprowadzonych badań}

Komitet Organizacyjny ŚDM w Krakowie w 2016 roku podał, że w tym wielkim wydarzeniu uczestniczyło 350 tys. zarejestrowanych uczestników ze 182 krajów świata. Wśród nich największą grupę stanowili Polacy - 79 tys., Włosi - 62 tys., Francuzi - 32 tys., Hiszpanie - 30 tys. i Amerykanie z USA - 23 tys. Na szóstym miejscu uplasowali się Niemcy, których było 11 792. Wśród zarejestrowanych uczestników ŚDM przeważały kobiety, które stanowiły 56 proc. wszystkich zgłoszonych osób. Większość (56 proc.), zarejestrowanych uczestników miała od 18 do 30 lat. 26 proc. uczestników liczyło mniej niż 18 lat, zaś osoby powyżej 30 roku życia stanowily 18 proc.

Opisywane w raporcie dane pochodzą z badania przeprowadzonego wśród uczestników ŚDM. Badanie przeprowadzone przez zespół Instytutu Statystyki Kościoła Katolickiego (ISKK) składało się z dwóch komponentów: ankiety elektronicznej przeprowadzonej wśród zarejestrowanych zagranicznych uczestników ŚDM z 20 krajów oraz z indywidualnych wywiadów z polskimi uczestnikami w diecezjach.

Ankieta elektroniczna została przeprowadzona metodą Computer Assisted Web Interview (CAWI) wśród zarejestrowanych uczestników ŚDM od 9 do 25 lipca 2016 roku. Została przygotowana w 8 językach: hiszpańskim, angielskim, niemieckim, portugalskim, francuskim, włoskim, słowackim i ukraińskim. Ankietę tę, wliczając polskich uczestników, wypełniło 11585 respondentów.

Narzędzie do badania metodą CAWI zostało opracowane na podstawie ankiety sporządzonej przez Australian Catholic University (Katolicki Uniwersytet Australii) z Melbourne do badania uczestników ŚDM w Sydney w 2008 roku. Indywidualne wywiady zostały przeprowadzone z uczestnikami dni w polskich diecezjach metodą pogłębionych wywiadów indywidualnych (individual in-depth interview) wśród 40 celowo dobranych osób. Do badania zostało wybranych 5 diecezji charakteryzujących się nie tylko 
odmiennym położeniem geograficznym w Polsce, ale również odmiennymi cechami religijności oraz poziomem rozwoju struktur parafialnych.

Dobór poszczególnych osób do tych badań polegał na wyborze młodzieży zaangażowanej w organizację dni w diecezjach. Dlatego w pierwszej kolejności rekrutacja polegała na kontakcie z diecezjalnym koordynatorem ŚDM, z prośbą o wskazanie parafii, w których jest zarejestrowana grupa zagranicznych uczestników ŚDM. Następnie z parafii miejskich oraz parafii wiejskich były dobierane po 4 osoby w podziale według płci, w wieku od 16 do 25 lat. Badanie zostało przeprowadzone przez odpowiednio przygotowanych ankieterów, mających wykształcenie socjologiczne według wytycznych do wywiadów.

Jakie są rezultaty przeprowadzonych badań, a więc jak wygląda religijny portret młodego człowieka?

$\mathrm{W}$ odpowiedzi na to pytanie ukazane zostaną w świetle badań następujące zagadnienia: elementy postaw religijnych (wiara i tożsamość religijna, praktyki i doświadczenie religijne, moralność, przynależność do małych grup religijnych, stosunek do instytucji Kościoła, papieża i biskupów, świadectwo i ewangelizacja), a następnie trajektorie socjalizacji religijnej (rola rodziców, doświadczenie buntu i wewnętrzna przemiana, odbiór parafii i lekcje religii, rola duszpasterzy, odkrywanie powołania). W zakończeniu zostaną przedstawione podstawowe wnioski.

\section{Elementy postaw religijnych}

Z przeprowadzonych badań wynika, że uczestnicy ŚDM to osoby wierzące. Jedynie 4,4 proc. spośród młodych ludzi stwierdzało, że nie są pewni swojej wiary, a zaledwie 0,4 proc., że są niewierzący. Badani wykazywali się także wysokimi wskaźnikami akceptacji podstawowych treści wiary Kościoła katolickiego. Ponad 70 proc. badanych przyznało, że akceptuje podstawowe treści nauczania dogmatycznego Kościoła katolickiego. Pod tym względem młodzież z Polski objęta badaniem cechowała się znacznie wyższymi wskaźnikami niż ogół respondentów. Około 90 proc. badanych z Polski stwierdzało, iż „wierzy bez wątpliwości” w takie treści wiary jak dziewictwo Maryi, transsubstancjacja czy bóstwo Chrystusa. 
Nie dostrzegało się natomiast znaczącej różnicy pomiędzy Polakami a badanymi z innych krajów pod względem stosunku do sakramentów oraz do liturgii Kościoła. Ponad 85 proc. przyznawało, że sakramenty Kościoła są bardzo ważne w ich relacji z Bogiem, a ponad 75 proc. podkreślało, że ważne są dla nich nabożeństwa katolickie, takie jak adoracja Najświętszego Sakramentu.

Niemal wszyscy zarejestrowani uczestnicy ŚDM były to osoby regularnie praktykujące (88,6 proc.) w każdą niedzielę lub częściej, w dni powszednie. Jeśli chodzi o modlitwę, zdecydowana większość badanych przyznaje, że modli się przynajmniej raz dziennie (66 proc.). Wśród polskich badanych odsetek ten był jeszcze wyższy (odpowiednio 96,2 i 81 proc.).

Pod względem form modlitwy najbardziej popularna jest modlitwa za bliskie osoby. Ponadto młodzi przede wszystkim rozmawiają z Bogiem własnymi słowami oraz proszą o wskazówki w podejmowaniu decyzji. Niemal wszyscy również błagają Boga o wybaczenie grzechów i wyrażają swoją miłość do Niego. Prawie wszystkich badanych modlitwa polega też na powtarzaniu wyuczonych na pamięć tekstów (96,5 proc.) oraz dziękczynieniu Bogu za otrzymane błogosławieństwo. Rzadziej modlitwa obejmuje intencje związane ze sprawiedliwością społeczną. Z modlitewnika korzysta niewiele ponad połowa badanych. Modlitwa rzadziej jest prostym trwaniem przy Bogu oraz proszeniem o rzeczy materialne. "Czytam fragment z Biblii i rozważam jego treść" - stwierdzało 71,6 proc. badanych.

Pod względem poczucia bliskości Boga co czwarty badany (26,5 proc.) wskazywał, iż czuje Boga bardzo blisko. Wśród doświadczeń duchowych badani najczęściej wyrażają przekonanie, że Bóg posługuje się nimi jako narzędziem wobec innych (80 proc.), iż doświadczają czytelnej odpowiedzi na modlitwie (80 proc.), powołania do działania w określony sposób (77 proc.) oraz podejmują decyzję o przyjęciu Jezusa za Pana i Zbawiciela (76 proc.).

Niezwykle ważne są odpowiedzi młodych ludzi na tematy moralności katolickiej. Pod względem poglądów moralnych badani w zdecydowanej większości zgadzają się z nauczaniem Kościoła. Największą akceptacją cieszy się sprzeciw Kościoła względem kary śmierci oraz aborcji. Nieco mniej badanych zgadza się z nauczaniem Kościoła co do eutanazji 
i małżeństw homoseksualnych. Najmniejszą akceptacją cieszy się celibat księży (66,1 proc.) oraz czystość przedmałżeńska (62,5 proc.). Uczestnicy ŚDM z Polski zdecydowanie przewyższają badanych w zakresie wszystkich uwzględnionych kwestii za wyjątkiem kary śmieci.

Badania dowiodły, że szczególne miejsce w religijności ludzi młodych zajmuje wspólnota religijna. 72 proc. wskazuje, że należy do małej grupy religijnej. 42 proc. badanych przynależących do wspólnot religijnych podejmuje w ramach swojej wspólnoty działalność ewangelizacyjną, zaś 42 proc. działalność charytatywną. Pod względem aktywności wspólnoty religijne najczęściej mają charakter modlitewny. Ponad 77 proc. wspólnie się modli. Ponad połowa z nich podejmuje rozważanie Pisma Świętego, a 68 proc. pogłębianie wiedzy religijnej. 61 proc. organizuje wspólne wyjazdy takie jak rekolekcje. Mniejsza część prowadzi działalność ewangelizacyjną (42 proc.) oraz charytatywną (39 proc.).

Z danych wynika, że połowa uczestników przyjechała na ŚDM z grupa parafialną, 18 proc. z grupą wywodzącą się z ruchu, a 11 proc. z rodziną lub znajomymi. Polacy częściej jechali do Krakowa z parafią (58 proc.) i rodziną lub znajomymi (13 proc.), natomiast rzadziej z grupą wywodzącą się z ruchu (11 proc.). Należy jednak pamiętać, że wyjazd polskiej młodzieży do Krakowa miał inny charakter niż wyjazd zagranicznych uczestników ŚDM, którzy musieli pokonać nieraz tysiące kilometrów. Z wypowiedzi polskich uczestników wyraźnie wynika, że na religijność młodych istotny wpływ wywiera przynależność do różnego rodzaju małych wspólnot religijnych. Osoby, które należą do tego typu grup, odczuwają poczucie duchowego wsparcia. Wspólnota wzmacnia ich wiarę i religijność. Dostrzec można również, że osoby zaangażowane w różnego rodzaju ruchy i wspólnoty charakteryzuje bardziej osobisty i mniej intelektualno-formalny stosunek do Kościoła i treści wiary. Natomiast osoby, które nie przynależą do żadnych wspólnot, częściej wspominają o trudnościach w prowadzeniu życia duchowego.

Wśród badanych uczestników ŚDM dostrzec można stosunkowo mało pozytywny stosunek do instytucji Kościoła. Chociaż znacznie ponad połowa badanych (68 proc.) uważa, że Kościół odpowiada na potrzeby duchowe człowieka, to niewiele ponad połowa uważa, że Kościół skutecznie rozwiązuje dylematy związane z życiem rodzinnym (59 proc.) i moralnością 
(52 proc.). Jedynie 38 proc. uważa, że Kościół właściwie odpowiada na wyzwania społeczne i polityczne. Polscy badani charakteryzują się bardziej negatywnym stosunkiem do Kościoła niż ogół badanych. Dotyczy to również przekonania, że papież i biskupi mogą wskazywać katolikom, w co mają wierzyć i jak postępować. Podczas gdy 75 proc. badanych zgadza się z takim stwierdzeniem, odsetek polskich badanych jest niższy i wynosi 71 proc. Jeśli chodzi o papieża Franciszka, badani podkreślają przede wszystkim jego skromność, bliskość z ludźmi, pokorę i ubóstwo.

\section{Trajektorie socjalizacji religijnej}

Kolejną sprawą podjętą w badaniach uczestników ŚDM są tzw. trajektorie socjalizacji religijnej. Mianem tym objęte są badania nad rolą rodziców w kształtowaniu postawy religijnej, doświadczenie buntu i wewnętrzna przemiana młodych, odbiór parafii i lekcje religii, rola duszpasterzy oraz odkrywanie powołania.

Uczestnicy ŚDM wzrastali w katolickich rodzinach. Ogółem 96 proc. przebadanych zarejestrowanych uczestników pochodziło z rodziny, w której matka była katoliczką. Wśród polskich zarejestrowanych uczestników odsetek ten stanowił aż 99 proc. Dla porównania znacznie mniej, bo 87 proc. przebadanych uczestników z Australii i 75 proc. z Ukrainy wychowywanych było przez matkę, która była katoliczką.

Rola rodziców w kształtowaniu się religijności jest ogromna. Motywują oni do praktyk religijnych, przypominają o religijnych wartościach oraz podstawowych zasadach chrześcijaństwa. Z wypowiedzi uczestników ŚDM rysuje się obraz wskazujący, że religijność rodziny stanowi podstawę do osobistych poszukiwań przez młodych wiary oraz odnajdywania swojego miejsca w Kościele. Wpływ na wychowanie do wiary miał również przykład rodziców. Młodzi wspólnie z rodzicami uczestniczyli w niedzielnych mszach świętych oraz modlili się w domu. Okazją do wzmacniania wiary są rozmowy na tematy religijne $\mathrm{w}$ domu. $\mathrm{Z}$ wypowiedzi wynika, że szczególną rolę w wychowaniu religijnym młodych zajmuje matka. To z nią młodzi najczęściej podejmują rozmowy na temat wiary. Jej przykład oddziałuje na postawy młodych, nawet jeśli jej religijność nie jest tak silna. 
Wyraźnie odmienne relacje mają młodzi ze swoimi ojcami. Naznaczone są one nieraz trudnościami oraz emocjonalnymi zmaganiami. $Z$ wypowiedzi badanych wynika, że na religijność młodych mniejszy wpływ niż rodzice ma rodzeństwo. Uczestnicy ŚDM potrafią także krytycznie ocenić religijność swoich rodziców. Dostrzegają hipokryzję religijną w rodzinie, czyli niespójność przyjmowanych postaw z wyznawaną wiarą.

Z wypowiedzi młodych osób na temat historii ich własnej religijności wynika, że proces rozwoju religijnego i odkrywanie własnej religijności jest niezwykle dynamiczne. Droga młodych do wiary i Kościoła ma często dramatyczny przebieg. Pojawiają się na niej okresy buntu i rozpaczliwego odrzucania wiary i Kościoła. Młodzi potrafią krytycznie wyrażać się na temat tych trudnych dla nich momentów. W czasie buntu szukają granic własnej wolności: próbują alkoholu i papierosów. Młodzi przyznają się do nieuczciwości oraz moralnego zagubienia. Przeżywany bunt łączył się często bezpośrednio z religijnością i polegał na odrzuceniu przekazanego przez rodziców obrazu Boga i niechęci do praktyk religijnych. Proces przezwyciężania buntu i wewnętrznej integracji przybiera różne formy. U niektórych osób polega na stopniowej i jakby niezauważalnej dla nich samych przemianie, zadawaniu sobie egzystencjalnych pytań dotyczących sensu życia, dobra i zła oraz Boga.

Nierzadko uspokojenie i przełamanie buntu młodzi zawdzięczają innym. Są to zarówno rodzice, jak i duszpasterze lub psychologowie. Oni to wywieraną presją pomogli młodym w przełamaniu okresu buntu, motywując ich do udziału w wydarzeniach religijnych lub do włączenia się do wspomnianych wyżej wspólnot, w których dokonała się ich przemiana. $\mathrm{Na}$ wewnętrzną przemianę młodych duży wpływ miały wyjazdy na rekolekcje we wspólnotach religijnych, gdzie często doświadczali bliskości Boga.

Jeśli chodzi o odbiór parafii, z uzyskanych wypowiedzi wynika, że młodzi krytycznie oceniają głoszone w parafiach kazania. Wyraźnie odróżniają jakość kazań księży, których można posłuchać w internecie, od tych zwyczajnych, które słyszą w swoich parafiach. Ich zdaniem jakość kazania zależy od osobowości księdza. Są bowiem tacy duchowni, którzy zbierają wokół siebie rzesze ludzi, i są też tacy, którzy odpychają. Oceniając lekcje religii, młodzi uczestnicy ŚDM podkreślają, że przekazują one niezbędną wiedzę, ale nie mają praktycznie wpływu na ich wiarę. Podobnie 
jak w przypadku kazań uważają, że na jakość lekcji religii wpływa osobowość nauczyciela. Młodych pociąga osobiste świadectwo katechety.

Badania uczestników ŚDM pokazują ważną rolę duszpasterzy w religijnym dojrzewaniu młodzieży. To właśnie księża umożliwiają młodym doświadczenie religijne i wprowadzają ich w głębokie życie religijne. Młodzi są wdzięczni księżom, że służą im radą i rozmową. Rola duszpasterzy jest wyraźna przede wszystkim w okresie buntu. Mądry ksiądz może być dla młodych dużym autorytetem.

Ostatnią kwestią poruszoną w ramach tzw. trajektorii socjalizacji religijnej był problem odkrywania swego powołania. Temat ten rzadko pojawia się w wypowiedziach badanych. Powołanie, rozumiane szeroko, jako plan Boga względem człowieka wierzącego, pojawia się jedynie sporadycznie. Najczęściej młodzież rozumie tę kwestię jako powołanie do życia konsekrowanego lub kapłaństwa. Myśli takie pojawiały się u niektórych we wczesnej młodości i wynikały często z dziecinnej fascynacji świętością. Jednakże w miarę upływu czasu życie codzienne je weryfikowało i oddalało to „idylliczne” pragnienie. Zdaniem niektórych powołanie „nosi znamiona swoistego wyroku i skazania". Gdy pojawia się myśl o kapłaństwie, ważną rolę w rozpoznaniu drogi powołania pełni wspólnota religijna oraz kontakt z księżmi i seminarium duchownym.

\section{Wnioski końcowe}

Badania nad fenomenem Światowych Dni Młodzieży, jakie odbyły się w lipcu 2016 roku w Polsce, a zwłaszcza w Krakowie, pozwalają dać szereg odpowiedzi na sformułowane na początku mego wystąpienia pytanie: jaka jest kondycja religijno-moralna współczesnej młodzieży. Niewątpliwie wydarzenie to zgromadziło młodzież o najwyższych wskaźnikach religijności, elitę młodych katolików zaangażowaną również w różnego rodzaju ruchy i grupy religijne. Większość badanych przyjechała na ŚDM z grupą parafialną oraz z inspiracji znajomych i kolegów. Badania dowiodły, że religijność uczestników ugruntowana jest w wierze rodziców, a zwłaszcza matki. Dostrzec można twórczą ciągłość wiary pomiędzy zaangażowaną katolicką młodzieżą a ich rodzicami. Moment przełomowy dla osobistego 
zaangażowania w życie wiary przypada najczęściej na etap wchodzenia w dorosłość. Wpływ na niego mają przede wszystkim wspólnoty i ruchy religijne, wyjazdy rekolekcyjne oraz osobisty kontakt z duszpasterzem. Jednak bezpośrednio najsilniejszy wpływ na postawy religijne młodzieży mają ich rówieśnicy. Osobiste odkrycie wiary przez uczestników ŚDM poprzedzone bywało okresem buntu oraz negowania przekazywanych przez rodziców zasad.

Podczas ŚDM młodzi zobaczyli wyraźnie kontrast między „starymi bukłakami”, czyli polską, tradycyjną religijnością parafialną, a „młodym winem”, czyli religijnością ruchów charyzmatycznych - ekspresyjną, emocjonalną, opartą na żywym świadectwie i żywej dynamice głoszenia kerygmatu $^{12}$. Nie jest jednak prawdą, jakoby nowe formy stanowiły całkowite zerwanie ze starymi formami, takimi jak tradycyjna droga krzyżowa, która stanowi wciąż najważniejszy punkt piątkowego programu ŚDM.

Badania dowiodły, że na tle zagranicznych uczestników polska młodzież charakteryzuje się wyraźną przewagą religijną w zakresie praktyk religijnych, akceptacji prawd wiary, zasad moralnych, jak również nieznacznie wyższym doświadczeniem obecności Boga. Z drugiej jednak strony polskich badanych charakteryzuje bardziej receptywne doświadczenie religijne oraz wyższe poczucie grzechu. Polscy badani częściej korzystają z Pisma Świętego i modlitewnika w osobistej modlitwie. Mniejsza część polskich badanych należy do wspólnot religijnych. Polacy charakteryzują się też mniej pozytywnym odniesieniem do instytucji Kościoła oraz nieco słabszym nastawieniem ewangelizacyjnym. Religijność badanych Polaków ma też znacznie słabszą orientację socjalną, czyli nastawienie na kwestie społeczne. Polscy uczestnicy ŚDM nie dostrzegają istotnego wpływu ewangelizacyjnego lekcji religii oraz zwyczajnego duszpasterstwa parafialnego na swoje postawy.

Podsumowując, należy stwierdzić, że wyniki podjętych badań prowadzą do wniosku, iż należy budować takie środowiska duszpasterskie, które stanowią przestrzeń osobistego zaangażowania młodych osób i dają im możliwość osobistego kontaktu zarówno z innymi młodymi, świadomie wyznającymi swoją wiarę, jak też osobistego kontaktu z duszpaste-

12 M. Rogaczewska, Znudzeni rutyna, dz. cyt., s. 89. 
rzami. Ponadto budowanie duszpasterstwa młodzieży powinno opierać się przede wszystkim na osobistych relacjach rówieśniczych. Chodzi tutaj nie tylko o świadectwo osób młodych w swoim środowisku, ale również o wykorzystanie koleżeńskich i przyjacielskich relacji do angażowania w środowiska duszpasterskie. 


\section{Summary}

\section{Religijny portret młodego uczestnika Światowych Dni Młodzieży 2016}

W związku z faktem, iż o religijnym obliczu Kościoła w najbliższych dziesiątkach lat decydować będzie obecne pokolenie młodzieży, warto zadać pytanie:jaka jest kondycja religijno-moralna współczesnej młodzieży? Znakomitą okazję do przyglądnięcia się tej kondycji stworzyły Światowe Dni Młodzieży, jakie odbyły się pod koniec lipca 2016 roku w Krakowie. Poniższy artykuł, Bazując na badaniach Etapy socjalizacji religijnej i elementy postaw religijnych uczestników Światowych Dni Młodzieży w 2016 roku, które przeprowadził Instytut Statystyki Kościoła Katolickiego w Polsce wśród uczestników Światowych Dni Młodzieży, w artykule podjęto próbę nakreślenia religijnego portretu młodego katolika początku XXI wieku.

W artykule tym ukazano genezę, cele, historię Światowych Dni Młodzieży w świecie i w Polsce.Zaprezentowano metodologię badań przeprowadzonych wśród uczestników Światowych Dni Młodzieży latem 2016 roku. Następnie omówiono elementy postaw religijnych, a więc wiarę, utożsamianie się młodych z Kościołem, ukazano praktyki religijne młodzieży, przytoczono opinie młodzieży na tematy moralności, świadomość przynależności młodzieży do parafii i do ruchów religijnych, w końcu zaś stosunek do instytucjonalnego Kościoła.

Podsumowując, należy stwierdzić, że dla życia wiarą, dla świadomego wyznawania jej ważną rolę pełni doświadczenie przynależenia i wspólnoty.

Słowa kluczowe: Światowe Dni Młodzieży 2016, religijność młodego katolika, religijny portret, młodzi, Kościół

\section{A Religious Portrait of a Young Participant from WYD 2016}

Considering the fact that the present young generation shall decide about the religious face of the Church in the years to come, it is worth asking - "what is the religious and moral condition of young people today?" A perfect opportunity to have a close look at this condition was provided by the World Youth Day taking place in Krakow in 2016. The present article, based on study conducted by The Institute of Statistics of the Catholic Church in Poland among participants of the World Youth Day and entitled: Stages of Religious Socialization and Elements of Religious Attitudes of Participants of the World Youth Day in 2016 undertakes an attempt to draw a religious portrait of a young Catholic at the beginning of the $21^{\text {st }}$ century.

The article shows the genesis, objectives and history of the WYD in the World and in Poland. It presents the methodology of studies conducted among participants of the World Youth Day in summer 2016. Next, follows the discussion of religious attitudes, that is the faith and the identification of young people with the Church, 
presentation of their religious practices, their opinions on moral issues, awareness of membership of parish communities and religious movements and finally, attitude towards Church as an institution.

Summing up, it should be concluded that the experience of membership and participation in the life of community plays an important role in the life in faith and its conscious professing.

Keywords: World Youth Day in 2016, religiosity of a young Catholic, young Pilgrim

from WYD 2016, religious Portrait, Catholic Church, youth

\section{Bibliografia}

Odbiór Światowych Dni Młodzieży i jego kulturowe konteksty. Raport z badania uczestników Światowych Dni Młodzieży Kraków 2016, http://iskk.pl/kosciol-na-swiecie/251world-youth-day (18.04.2017).

Czas na młodych: idziemy za papieżem Franciszkiem, red. S. de Moustier, przekł. A. Kocot, Poznań 2016.

Czekalski R., Korelacja nauczania religii w szkole z katecheza parafialna, w: Rodzina szkoła - Kościół. Korelacja i dialog, pod red. P. Tomasika, Warszawa 2003, s. 59-72.

Długosz A., Młodzieży duszpasterstwo, w: Encyklopedia katolicka, t. 12, red. A. Bednarek, Lublin 2008, s. 1444.

Dziedzic J., Religijność a postawy moralne polskiej młodzieży. Refleksja psychologiczno-pastoralna, w: Młodzież nadzieją Kościoła - czy Kościótjest nadzieją młodzieży?, red. J. Dziedzic, M. Ostrowski, T. Panuś, Kraków 2017, s. 187-204.

Etapy socjalizacji religijnej i elementy postaw religijnych uczestników Światowych Dni Młodzieży w 2016 roku, oprac. W. Sadłoń SAC, Warszawa 2016.

Lipiec D., Teologiczne podstawy duszpasterstwa młodzieży, „Warszawskie Studia Pastoralne UKSW" 2 (2014), s. 11-12.

Müller Ph., Młodzież i Kościót w Niemczech, w: Młodzież nadzieja Kościoła - czy Kościót jest nadzieją młodzieży?, red. J. Dziedzic, M. Ostrowski, T. Panuś, Kraków 2017, s. 61-73.

Ostrowski M., Młodzież w oczach papieży na podstawie przemówień, podczas Światowych Dni Młodzieży, w: Młodzieżnadzieją Kościoła - czy Kościół jest nadzieją młodzieży?, red. J. Dziedzic, M. Ostrowski, T. Panuś, Kraków 2017, s. 15-30.

Panuś T., Obraz polskiej młodzieży po piętnastu latach nauczania religii w szkole - wnioski socjologiczno-pastoralne, w: Polska katecheza wobec pluralizmu jednoczacej się Europy, red. A. Offmański, Szczecin 2004, s. 83-102.

Pielgrzymka odwagi i nadziei. Franciszek w Polsce z młodzieżąśsiata, red. J. Sosnowska, Kraków 2016.

Rogaczewska M., Znudzeni rutyna, „W Drodze” 4 (2017), s. 87-88. 